\title{
Educational Management Study On College For Islamic Instruction
}

\author{
$1^{\text {st }}$ Jujris \\ Departement of Education Science \\ Universitas Negeri Makassar \\ Makassar, Indonesia \\ $4^{\text {th }}$ Darman Manda \\ Departement of Education Science \\ Universitas Negeri Makassar \\ Makassar, Indonesia
}

\author{
$2^{\text {nd }}$ Patta Bundu \\ Departement of Education Science \\ Universitas Negeri Makassar \\ Makassar, Indonesia
}

\author{
$3^{\text {rd }}$ Jasruddin \\ Departement of Education Science \\ Universitas Negeri Makassar \\ Makassar, Indonesia
}

\begin{abstract}
The objective of this research is to find out the educational management in Madrasah Tsanawiyah (MTs) in Dompu Regency, especially regarding program planning, program implementation, evaluation and supervision, leadership, and management information system development. The other side is the formation of trust and active community participation in the madrasa program in Dompu District. The research was conducted in MTsN 2 Dompu, MTs Al-Kautsar, MTs Al-Rashid, and MTs Darul Ulum of Dompu Regency. The research subjects are headmaster of madrasas, deputy head of madrasas, teachers, educational staffs, students, madrasas committee, community, and official of Ministry of Dompu Regency. Data collection techniques were observation, interviews, documentation, and questionnaires. The data were analyzed trough reduction data, display data, conclusion or verifying. The data were obtained from the informants who have been selected as the object of research using purposive sampling. The participants were chosen because they represent some elements of the region, elements of community heterogeneity, and culture. The results showed that the educational management in state madrasas managed by the government namely the Ministry of Religion shows the fulfillment of education management standards in which one of the indicators is having madrasa development plan. In contrast, madrasas held by the community, in this case, the foundation experienced stagnation and tended to be decreased.
\end{abstract}

Keywords-Educational Management, Madrasa, Perception

\section{INTRODUCTION}

Madrasa as a part of national education providers is currently required to be able to carry out education in accordance with national education standards formulated by the Government [1]-[4]. The standardization is according to Government Regulation No. 19 of 2005, which has been amended by Regulation No. 32 of 2013. The regulation includes competency standards, content standards, standardized processes, education personnel standards, improved facilities and infrastructures, management standard, educational funding standard, and educational assessment standards.

By conducting the standardization process of education, it is expected that madrasa can compete with public schools, especially in the implementation of general knowledge [5], [6]. Notably, in the process of managing education, the government has encouraged educational autonomy [7]-[13].
Thus, the madrasa can be more flexible in conducting school management processes that lead to the improvement of the quality of madrasas.

The presence of madrasa as formal and Islamic educational institutions is in line with national education objectives. It, in fact, becomes the answer for strengthening faith, piety and the development of the morality of learners. It is what distinguishes between the substance of learning in the madrasa and public schools. In public school, there is one subject of religious education, while madrasa has four subjects of Islamic education namely Aqidah Akhlak, AlQur'an Hadits, History of Islamic Culture and Fiqh.

The Law number 20/2003 on national education system aligned madrasa with public schools, in its position as formal education. However, the alignment of the status and position of madrasa with schools in the field of education in the National Education System does not necessarily require the management of madrasa affairs to be autonomy [14], [15].

Educational institutions symbolizing Islam such as madrasa or pesantren have been the primary choice of society for the place of education of their sons and daughters at that time. There has been no scientific research that examines how madrasa education is the primary choice for the people at Dompu regency. There were also no researchers who analyzed the decreased public interest in pesantren or madrasa education. However, the current phenomenon shows that people in Dompu who still hold religious values, in general no longer make madrasa as educational institutions a primary choice and a symbol of pride in the education of their children.

Data from the Ministry of Religion office in 2016/2017 in Dompu Regency shows that the number of madrasas in Dompu Regency is quite significant, namely 116 madrassas consisting of MI, MTs and MA levels in which the total number of students is 6,544. From the 116 madrassas, 112 are owned by the community or have a private status, and there are only four state madrasas. There are 1,057 teachers from the three madrasas levels above consisting of 96 civil servants and 961 non-civil servants. From 96 civil servant teachers, three have a master's degree (S2), 70 are undergraduate (S1), and the remaining 23 are diploma level. Non-civil servant madrasa teachers who are undergraduate 
level are 638 people, and the rest 232 are diploma-educated and below.

[16] found that the causes of the decreasing in public interest on madrasa education are the result of limited supporting facilities, including non-human resources, human resources, physical resources and financial resources. It has an impact on the development of the Human Development Index (HDI) in Dompu Regency.

In 2015 the HDI of Dompu Regency was in the 5th rank at the level of the Province of West Nusa Tenggara or number 424 nationwide with $82.80 \%$ Literacy Rate and Drop out (DO) $4.88 \%$. These facts show that efforts to improve the quality of education, especially madrasas in Dompu Regency still face significant challenges. Therefore, comprehensive policy and policy support are needed so that efforts to improve the quality of human resources are thriving in a short time. One of the strategies is to involve all existing education stakeholders from the government, legislative, private and community [17]-[20].

The issue of madrasa education institutions as described above shows that there is a problem of developing madrasa education in Dompu Regency that needs to be studied through scientific research. The phenomenon clearly shows that madrasas as an educational institution that has become the pride of Dompu society have shifted into "second-class" and "marginal" from educational institutions either public, private or public institutions. Another exciting thing is that there are still some madrassas which are considered a favorite educational institution for the people at Dompu regency.

Based on the description above, the researchers formulate the following research problems:

1. How is the description of educational management in college for Islamic instruction in Dompu regency?

2. How is the description of public perception towards college for Islamic instruction in Dompu regency?

3. What are the supporting factors of educational management in college for Islamic instruction in Dompu Regency?

4. What are the inhibiting actors of the educational management of college for Islamic instruction in Dompu regency?

\section{RESEARCH METHODS}

This research was qualitative research [21], [22]. The qualitative research describes the phenomena and circumstances that occur at the research location based on the scientific conditions of the research object. This research was conducted in four madrassas namely Madrasah Tsanawiyah (MTs) Al-Kautsar Ranggo, Madrasah Tsanawiyah (MTs) Al-Rasyid Sawe, and Madrasah Tsanawiyah (MTs) Darul Ulum Daha. The data sources in this study were primary data and secondary data. The data were collected using questionnaire, observation, interview, and documentation.

The main instruments are the researchers themselves while the supporting devices used in data collection were questionnaire guidelines, observation sheets, interview guidelines, and documentation checklists. The data that had been collected were then processed with descriptive qualitative analysis. Data processing took place simultaneously with the process of collecting data through three stages, namely data reduction, data presentation, and data verification. Conclusions were drawn from the inductive analysis. It was the discussion of specific matters, and it was then concluded through general matters.

The validity of the data was tasted based on four criteria, namely the degree of credibility, transferability, dependability, confirmability. However, in testing the validity of the data in this study, the researchers only uses the criteria of the degree of credibility and confirmability, because the data had been saturated.

Furthermore, triangulation was a technique for testing the validity of data by utilizing various sources outside the data as the results of the research which can be accounted for in which the researchers attempt to test the validity of the data obtained from one source with another source.

\section{RESULTS AND DISCUSSION}

The educational management in madrassas has been implemented [23], [24]. The planning procedures have been arranged. It starts from the concept prepared by madrasas, then brought to the madrasa work meeting and set together between the head of madrasas, teachers, and madrasa committee. These activities were carried out at the beginning of the school year. Supervision of the drafting of the madrasa work plan was carried out by the head of the madrasas. In addition, the evaluation or performance appraisal was also carried out by the head of the madrasas. The validated madrasa work plan both the model and its contents was not yet in-depth studies that were in direct contact with the needs of the local community.

The educational management public madrasas are relative to meet the national education standards set by the government [1]. On the other hand, the madrasas managed by the community does not have a madrasa development plan so that the implementation of the program seems incidental based on the needs at that time.

The description of community perceptions of madrassas in Dompu is quite diverse and positive. For some societies, madrassas are considered as an ideal educational institution to entrust their children with good knowledge of general knowledge especially knowledge of Islam (especially state madrasas). Referring to this statement, the improvement of community perceptions can increase community interest in madrasas. It was proven that the madrasas which were imaged negatively by the societies would change in line with the increase in performance of the madrasas, such as having a permanent building and uniform, facilities and infrastructure, support learning. Furthermore, the madrasa improves coaching as ideals and desire of parents of students and society. Islamic education institutions, in particular, will be the expectations of parents of students because they can transform the values of Islamic teachings both for the interests of the world and hereafter. Therefore, parents of students feel safe and comfortable sending their children to madrasas. 
Supporting factors in the educational management of madrasas are inseparable from the climate created by madrasah organizers and managers, namely the religious atmosphere and the cultivation of noble character. The atmosphere that is accustomed to the madrasas will ensure the integral value and basic competence of Islamic teachings. Therefore, the children will grow and develop with Islamic personality. It will have a positive impact on public trust in madrasas.

If the madrasa is managed by a professional management system which can understand and respond to the demands and aspirations of the community, the institution will have more significant opportunities to become the first top choice for the community. Educational management is defined as the process of planning, organizing, leading, controlling education personnel, educational resources to achieve educational goals, educating the life of the nation, developing the full potential of humans.

The inhibiting factor in the educational management is the complexity of the problems faced by madrassas which primarily originate from its own education system, namely its inability to balance the dynamics of the community's need for higher quality education and the dynamics of culture in general. Besides that, madrasas are considered like stepchildren by the government themselves and treated as second-grade schools. As a result, public appreciation of madrasas is generally less encouraging. The reality in the field shows that madrasa output for some people is still considered to be of poor quality and has not been able to compete with public schools. The management system of education acutely influences it in each institution in response to the dynamics of the community.

The educational institution duty is weighty. Therefore, in its management, it is not free from some of the obstacles. In addition to those described in the previous section, there are several other inhibiting factors in the management of madrasa namely students, educators, funds and infrastructure, and community participation.

The students have different bits of intelligence even though they have the same calendar age, but their mental abilities are not the same. The existing differences can become obstacles to the development of aspects of students themselves which in turn is an obstacle to the development of education.

Educator factors are also very decisive in the development of madrasas. Moreover, the condition of the teacher and family namely health, social psychological and economic well-being is a barrier or social factors that influence the progress of the implementation of the teacher's duties. It can be concluded that the level of financial security of teachers that is less secure will be a barrier to involvement as part of the educational management in madrasas.

Lack of funding and infrastructure facilities is a problem of education, including in Dompu Regency. Many educational institutions are less in the development due to lack of funding problems and infrastructure facilities while it is essential for the sustainability of educational institutions.

\section{CONCLUSION}

Educational management, in essence, is not the authority and obligation of the headmaster alone. However, in the management of madrasah, it is expected to involve the existing stakeholders. The involvement of all stakeholders is one of the necessary capital to support the realization of madrasa education management that meets the national standard of education.

The perception of the community toward the madrasas will depend on how the organizers manage education which takes a side to community needs, especially relating directly to the curriculum, educators, leadership, and management information systems.

Supporting factors for educational management are madrasa head management, curriculum, teacher competency, education budget, optimization of cooperation with the community. Educational management factors are lack of infrastructure, the way teachers teach which is not according to their educational background, and low teacher welfare.

\section{ACKNOWLEDGMENT}

The writer would like to express their thanks to all parties, especially for the reviewer team who have provided valuable suggestion and guidance in writing this article

\section{REFERENCES}

[1] M. Taher, M. Burhanuddin, dan A. Ahmed Khan, "Madrasa libraries in India," Int. Libr. Rev., vol. 21, no. 1, hal. 83-97, 1989. N. Rao dan M. I. Hossain, "Confronting poverty and educational inequalities: Madrasas as a strategy for contesting dominant literacy in rural Bangladesh," Int. J. Educ. Dev., vol. 31, no. 6, hal. 623-633, 2011.

[3] K. R. McClure, "Madrasas and Pakistan's education agenda: Western media misrepresentation and policy recommendations," Int. J. Educ. Dev., vol. 29, no. 4, hal. 334-341, 2009.

[4] T. Bourke, M. Ryan, dan P. Ould, "How do teacher educators use professional standards in their practice?," Teach. Teach. Educ., vol. 75, hal. 83-92, 2018.

[5] S. Aburizaizah, Y. Kim, dan B. Fuller, "Diverse schools and uneven principal leadership in Saudi Arabia," Int. J. Educ. Res., vol. 80, hal. 37-48, 2016.

[6] O. F. Bizri, "Chapter 6 - Arab Science, Technology, and Innovation Systems: Challenges, Policy Regimes, and Future Directions," O. F. B. T.-S. Bizri Technology, Innovation, and Development in the Arab Countries, Ed. Academic Press, 2018, hal. 503-569.

[7] Y. Wang dan R. K. H. Chan, "Autonomy and control: The struggle of minban schools in China," Int. J. Educ. Dev., vol. 45, hal. 89-97, 2015.

[8] P. Salinas dan A. Solé-Ollé, "Partial fiscal decentralization reforms and educational outcomes: A difference-in-differences analysis for Spain,” J. Urban Econ., vol. 107, hal. 31-46, 2018.

[9] G. C. Susar, "Implications of Student Cantered Education for the Neoliberal Regime of Government and Knowledge Economy in Turkey," Procedia - Soc. Behav. Sci., vol. 116, hal. 2293-2301, 2014.

[10] N. K. Shee, "Karen Education Department's multilingual education for language maintenance," Kasetsart J. Soc. Sci., 2018.

[11] C. Solano Lara, A. Fernández Crispín, dan M. C. López Téllez, "Participatory rural appraisal as an educational tool to empower 
sustainable community processes," J. Clean. Prod., vol. 172, hal. 4254-4262, 2018.

[12] J. Scheerens dan S. Blömeke, "Integrating teacher education effectiveness research into educational effectiveness models," Educ. Res. Rev., vol. 18, hal. 70-87, 2016.

[13] K. Lougheed, "AAfter the manner of the Irish schools': the influence of Irish national education in the British Empire," $J$. Hist. Geogr., vol. 60, hal. 1-10, 2018.

[14] A. Oleinik, "Does education corrupt? Theories of grade inflation," Educ. Res. Rev., vol. 4, no. 2, hal. 156-164, 2009.

[15] I. M. Johnson, "The impact on libraries and archives in Iraq of war and looting in 2003-A preliminary assessment of the damage and subsequent reconstruction efforts," Int. Inf. Libr. Rev., vol. 37, no. 3, hal. 209-271, 2005.

[16] M. N. Asadullah dan Maliki, "Madrasah for girls and private school for boys? The determinants of school type choice in rural and urban Indonesia," Int. J. Educ. Dev., vol. 62, hal. 96-111, 2018.

[17] R. Meissner et al., "South African local government perceptions of the state of water security," Environ. Sci. Policy, vol. 87, hal. 112-127, 2018.

[18] S. V Flanagan dan Y. Zheng, "Comparative case study of legislative attempts to require private well testing in New Jersey and Maine," Environ. Sci. Policy, vol. 85, hal. 40-46, 2018.

[19] E. J. Randle dan R. Hoye, "Stakeholder perception of regulating commercial tourism in Victorian National Parks, Australia," Tour. Manag., vol. 54, hal. 138-149, 2016.

[20] J. Irungu dan L. Kimencu, "15 - Trends in private higher education: The case of Kenya," M. Shah dan C. S. B. T.-A. G. P. on P. H. E. Nair, Ed. Chandos Publishing, 2016, hal. 255-269.

[21] J. w. Creswell, Research Design: qualitative, quantitative, and Mix Methods Approaches, Fourth. Los Angeles, USA: Sage Publications, 2014.

[22] J. W. Creswell, V. L. P. Clark, dan V. L. Plano Clark, Designing and conducting mixed methods research, vol. 2nd. Sage publications, 2017.

[23] A. Delavande dan B. Zafar, "Stereotypes and Madrassas: Experimental evidence from Pakistan," J. Econ. Behav. Organ., vol. 118, hal. 247-267, 2015.

[24] S. Malhis, "Narratives in Mamluk architecture: Spatial and perceptual analyses of the madrassas and their mausoleums," Front. Archit. Res., vol. 5, no. 1, hal. 74-90, 2016. 